http://nv.nltu.edu.ua

https://doi.org/10.15421/40281104

Article received $11.12 .2018 \mathrm{p}$.

Article accepted 27.12.2018 p.

$@ \bowtie$ Correspondence author

H. V. Stryamets

УДК 551.582

Г. В. Стрямець , В. О. Гребельна ${ }^{1}$, О. С. Скобало ${ }^{1}$, С. П. Стрямець ${ }^{1,2}$

${ }^{I}$ Природний заповідник "Розточчя", смт. Івано-Франкове, Україна

${ }^{2}$ Національний університет "Львівська політехніка", м. Львів, Україна

\title{
ЛОКАЛЬНІ ПРОЯВИ ЗМІН КЛІМАТУ НА ПРИКЛАДІ ПРИРОДНОГО ЗАПОВІДНИКА "РОЗТОЧЧЯ"
}

\begin{abstract}
Наведено аналіз метеопоказників, зафіксованих метеостанцією заповідника за останні десять років (2008-2017 рр.). Встановлена тривалість сезонів відзначається сильною варіабельністю, що є ознакою кліматичних змін: найкоротша за досліджуваний період зима тривала 30 днів, а найдовша - 125 днів. Тривалість весни зменшується, характерними рисами сезону є низька вологість повітря, холодні ночі, теплі дні, мала кількість опадів, що утруднює роботу аграріїв. Збільшується тривалість літа, середнє значення досягає 112 днів. Відзначено, що змінився характер опадів - дощ випадає у вигляді сильних короткочасних злив, за одну зливу може випасти місячна норма опадів; збільшилася кількість днів у році з високою температурою повітря, тривалість вегетаційного періоду зросла в середньому на 9 днів. На території природного заповідника "Розточчя" зафіксовано інші локальні прояви зміни клімату, які виражаються у такому: середньорічна температура повітря за останні десять років зросла на $1,4{ }^{\circ} \mathrm{C}$, а за останні п'ять років на $-1,7^{\circ} \mathrm{C}$, що перевищує норму $1,5^{\circ} \mathrm{C}$, рекомендовану експертами IPCC; почастішали аномальні явища природи: сніголами, вітровали, буревії, трапляються смерчі, урагани, які завдають збитків населенню - руйнують будівлі, знищують урожаї сільськогосподарських культур.
\end{abstract}

Ключові слова: тривалість сезонів; середньодобова температура повітря; опади; аномальні явища.

Вступ. Зміна клімату на планеті є однією з найбільш серйозних екологічних проблем сучасності, яка дедалі частіше стає причиною негативних наслідків для економіки та суспільства загалом. Термін "зміна клімату" в документах IPCC означає будь-які кліматичні зміни в часі як наслідок природних змін або як результат людської діяльності. Відзначено, що, ймовірно, є декілька причин глобальних змін клімату - це природна мінливість, яка циклічно відбувається всередині кліматичної системи; ймовірно, це наслідок вулканічних вивержень та змін у сонячній радіації; ймовірно, це чітко зареєстроване потепління на початку XX ст., що було спричинене також антропогенними чинниками (Stocker, 2013). Тому актуальним завданням є виявлення локальних змін клімату та розробки заходів адаптації до цих змін.

Мета роботи - проаналізувати метеорологічні показники, які фіксує метеостанція заповідника на предмет наявності чи відсутності локальних кліматичних змін за останніх десять років.

Огляд літературних джерел. Потепління кліматичної системи було зафіксовано у змінах температури поверхні грунту та атмосфери, температур поверхневих (глибиною до кількасот метрів) вод океану та завдяки підвищенню рівня світового океану. Спеціальні дослі- дження виявили антропогенний внесок до всіх цих перелічених змін.

25 жовтня 2018 р. Свропарламент прийняв резолюцію, якою закликав країни підвищувати свої зобов'язання у рамках Паризької угоди та робити все можливе для того, щоб утримати глобальне потепління на рівні 1,5 ${ }^{\circ} \mathrm{C}$. Зі звіту видно, що потепління на $2{ }^{\circ} \mathrm{C}$ несе набагато більше загроз, економічних втрат та незворотних наслідків, аніж потепління на $1,5{ }^{\circ} \mathrm{C}$ (Stocker, 2018). Глобальні та локальні прояви змін клімату наведено в багатьох наукових працях (Stocker, 2018; Kryvoruchenko, 2014; Skobalo et al., 2013).

Методика і методи дослідження. Метеорологічні спостереження в заповіднику здійснюють за загальноприйнятими методиками (Fylonov \& Nukhymovskaia, 1985; Andriienko et al., 2002), показники температури повітря фіксують кожні три години, кількість опадів за добу. Це фіксують у Літописах природи (Litopys pryrody, 2008-2017). Здійснюють статистичну обробку даних. Фенологічні спостереження ведуть відповідно до методики Шульца (1981), поділ на сезони і субсезони - відповідно до рекомендації Програми Літопису природи (Andriienko et al., 2002).

Результати дослідження та їх обговорення. Фенологічні та кліматичні характеристики Розточчя відріз-

\section{Інформація про авторів:}

Стрямець Галина Володимирівна, канд. с.-г. наук, ст. наук. співробітник, заступник директора з наукової роботи.

Email: galina.stryamets@gmail.com

Гребельна Валентина Омелянівна, мол. наук. співробітник. Email: zaproz25@gmail.com

Скобало Оксана Степанівна, мол. наук. співробітник. Email: zaproz25@gmail.com

Стрямець Сергій Петрович, канд. техн. наук, доцент, ст. наук. співробітник. Email: sergijstr@gmail.com

Цитування за ДСту: Стрямець Г. В., Гребельна В. О., Скобало О. С., Стрямець С. П. Локальні прояви змін клімату на прикладі природного заповідника "Розточчя". Науковий вісник НЛтУ України. 2018, т. 28, № 11. С. $24-28$.

Citation APA: Stryamets, G. V., Hrebelna, V. O., Skobalo, O. S., \& Striamets, S. P. (2018). Local effects of climate change on the example of the Roztochya nature reserve. Scientific Bulletin of UNFU, 28(11), 24-28. https://doi.org/10.15421/40281104 
няються від прилеглих територій підвищеною вологістю повітря, значною амплітудою коливань температури, надмірною кількістю опадів та сильними вітрами, що зумовлено складною орографією, густою гідрологічною сіткою, наявністю озер та великих лісових масивів, а також близьким розташуванням гірської системи Карпат, що теж зумовлює особливості місцевого клімату (Kosyk \& Skobalo, 2006; Babichenko \& Zuzuka, 1998). Регіон Розточчя розташований у перехідній зоні від помірно теплого західноєвропейського клімату до помірно-континентального східноєвропейського. Уся територія зазнає впливу західних повітряних мас, морського полярного та континентального тропічного повітря (Prots-Kravchuk, 1972). Температурні умови і режим зволоження мають найбільше значення для формування ландшафтів, розвитку лісового й сільського господарства та заповідної справи.

Для Розточчя характерна поступова зміна основних сезонів року, тому кліматичну характеристику доцільно навести за сезонами, їню тривалість наведено в табл. 1. Результати тривалості сезонів, наведені в цій таблиці, свідчать про їхню сильну варіабельність, що є ознакою кліматичних змін. Найкоротшою, за період, який розглядаємо, зима була в 2016 р. - 30 днів, а найдовшою - 125 днів у 2013 р. Тривалість літа збільшується і в окремі роки досягає 120 днів і більше, середня тривалість літа за досліджуваний період досягла 112 днів. Збільшилася тривалість вегетаційного періоду в середньому на 9 днів.

Табл. 1. Показники тривалості сезонів за 2008-2017 рр. у Природному заповіднику "Розточчя"

\begin{tabular}{|c|c|c|c|c|c|c|}
\hline \multirow{2}{*}{ Рік } & \multicolumn{4}{|c|}{ Початок сезону/тривалість сезону, день } & \multicolumn{2}{|c|}{ Тривалість, день } \\
\hline & зима & весна & літо & осінь & природного року & вегетації \\
\hline 2008 & $\frac{15.11 .07}{98}$ & $\frac{21.02 .08}{86}$ & $\frac{17.05 .08}{119}$ & $\frac{13.09 .08}{71}$ & 374 & 243 \\
\hline 2009 & $\frac{23.11 .08}{101}$ & $\frac{03.03 .09}{96}$ & $\frac{07.06 .09}{103}$ & $\frac{18.09 .09}{86}$ & 386 & 220 \\
\hline 2010 & $\frac{13.12 .09}{95}$ & $\frac{18.03 .10}{81}$ & $\frac{07.06 .10}{86}$ & $\frac{01.09 .10}{91}$ & 353 & 241 \\
\hline 2011 & $\frac{01.12 .10}{101}$ & $\frac{12.03 .11}{77}$ & $\frac{28.05 .11}{119}$ & $\frac{24.09 .11}{86}$ & 383 & 231 \\
\hline 2012 & $\frac{19.12 .11}{84}$ & $\frac{12.03 .12}{70}$ & $\frac{21.05 .12}{118}$ & $\frac{16.09 .12}{79}$ & 351 & 242 \\
\hline 2013 & $\frac{04.12 .12}{125}$ & $\frac{08.04 .13}{56}$ & $\frac{03.06 .13}{91}$ & $\frac{02.09 .13}{85}$ & 357 & 209 \\
\hline 2014 & $\frac{26.11 .13}{93}$ & $\frac{26.02 .14}{85}$ & $\frac{23.05 .14}{123}$ & $\frac{23.09 .14}{64}$ & 365 & 257 \\
\hline 2015 & $\frac{26.11 .14}{89}$ & $\frac{23.02 .15}{98}$ & $\frac{01.06 .15}{118}$ & $\frac{27.09 .15}{96}$ & 401 & 223 \\
\hline 2016 & $\frac{01.01 .16}{30}$ & $\frac{31.01 .16}{116}$ & $\frac{26.05 .16}{122}$ & $\frac{25.09 .16}{64}$ & 332 & 245 \\
\hline 2017 & $\frac{28.11 .16}{87}$ & $\frac{23.02 .17}{93}$ & $\frac{24.05 .17}{121}$ & $\frac{25.09 .17}{69}$ & 370 & 246 \\
\hline Середнє & 90 & 86 & 112 & 79 & 367 & 236 \\
\hline
\end{tabular}

Природний рік починається зимовим сезоном, який настає в перших числах грудня і триває в середньому 85 днів. Зимовий сезон $є$ найхолоднішим, обмежений датами стійкого переходу середньої добової температури повітря через $0{ }^{\circ} \mathrm{C}$ в період її зниження восени і підвищення навесні. Взимку дуже розвинута циклонічна діяльність, яка забезпечує інтенсивний обмін повітря i значну нестійкість погоди. У цей сезон відбуваються систематичні вторгнення холодних повітряних мас, які призводять до значного зниження температури повітря. Абсолютні максимуми повітря в зимовий період пов'язані з надходженням теплого повітря з Атлантики, а також із південно-західними вітрами. Найнижчі температури спричинені проникненням континентального арктичного повітря, яке приносить холодну і вологу погоду.

Зимою спостерігаємо найбільші зміни температури. Характерною особливістю зимового сезону є часті відлиги. До холодної частини зими належить період із середньою добовою температурою повітря $-5{ }^{\circ} \mathrm{C}$ і нижче i триває в середньому близько 20 діб. Така температура встановлюється на початку січня, утримується до другої декади лютого. Зниження температури повітря до -10 ${ }^{\circ} \mathrm{C}$ і нижче спостерігаємо від січня до березня включно. Кількість днів із такою температурою припадає на січень-лютий і в середньому становить 4 дні. У холодні зими температура повітря може знижуватися до $-20{ }^{\circ} \mathrm{C}$ (2015 р.) і нижче - аж до $-29,0{ }^{\circ} \mathrm{C}$ (2012 р.). У середньому за зимовий сезон таку температуру повітря відзна- чаємо лише декілька днів, у лютому 2012 р. температура нижче $-20,0{ }^{\circ} \mathrm{C}$ опускалася протягом 8 днів. За зимовий сезон у середньому випадає 143,3 мм опадів або $20 \%$ від річної кількості, але взимку спостерігаємо найбільшу кількість днів 3 опадами і найбільшу їхню тривалість. У холодний період року частина опадів випадає у вигляді снігу. Сніговий покрив добре захищає грунт від холоду, тому що має низьку теплопровідність. Стійке залягання снігового покриву зберігається у середньому 66 днів (від середини грудня до кінця першої декади березня). До аномальних явищ, які проявляються в зимовий період, належать буревії, сніголами, грози (27.01.2008 р.). Нове аномальне явище - обледеніння гілок, плодів - тривало з 21.01.2013-29.01.2013 рр., утруднило харчування багатьох видів диких птахів і звірів.

Весна - це період зі стійкою середньою добовою температурою повітря від $0{ }^{\circ} \mathrm{C}$ до $+10{ }^{\circ} \mathrm{C} .3$ переходом середньої добової температури повітря через $0{ }^{\circ} \mathrm{C}$ в бік iï підвищення закінчується холодний період і розпочинається теплий. На Розточчі за останні 5 років весна розпочиналася досить швидко, в середньому в третій декаді лютого і тривала 89 днів. За термінами настання, весни поділяють на ранні та пізні, за температурним режимом - на теплі та холодні, а за характером розвитку - на дружні та затяжні. Погода протягом весняного сезону характеризується неоднорідністю та мінливістю. На початку весни ще зберігаються деякі зимові риси, а для кінця весни характерні властивості літнього сезону. 
Особливістю весни $є$ інтенсивне підвищення середніх добових температур повітря та збільшення їі середньої добової амплітуди. Весняний сезон за характером розвитку атмосферних процесів і темпами зростання температури повітря можна поділити на дві частини. Перша частина весни (період зі стійкою середньодобовою температурою повітря від $0{ }^{\circ} \mathrm{C}$ до $+5^{\circ} \mathrm{C}$ ) ще зберігає риси зимового сезону. Друга - поділяється на два періоди. У перший період відбувається стійкий перехід середньої добової температури повітря через $+5{ }^{\circ} \mathrm{C}$. У другий період, 3 переходом температури через $+10{ }^{\circ} \mathrm{C}$, починається вегетація рослин. Період вегетації рослин триває в середньому 236 днів. Для весняного сезону характерні заморозки, які утворюються вночі та вранці. Найчастіше вони бувають адвентивно-радіаційними. Середня дата припинення весняних заморозків припадає на середину квітня. За весняний період випадає в середньому 180 мм опадів, що становить $24 \%$ від річної кількості. Кінцем весни і початком літа вважаємо стійкий перехід середньодобової температури повітря через $+10^{\circ} \mathrm{C}$.

Літо - сезон, який в умовах Розточчя має тенденцію до збільшення. Середня тривалість за п'ять років становить 115 діб, найбільша - 123 доби. Зазвичай, тривале літо характеризується високою середньою добовою температурою повітря, незначною кількістю опадів, великою кількістю сонячних днів, а коротке літо - більш низькою температурою повітря, великою кількістю опадів і значною кількістю похмурих днів. Відомо, що влітку головне місце серед кліматотвірних чинників належить сонячній радіації (Entsyklopediia, 1990). Висота сонця, тривалість сонячного сяйва мають найвищі за рік показники. Погодні умови літнього сезону не залишаються постійними, незважаючи на їхню стійкість, порівняно з іншими сезонами. На початку літа погода має відносно нестійкий характер: спостерігаємо похолодання, пов'язані із вторгненням повітря з півночі та північного заходу. У другій половині літа, коли переважає антициклонний тип погоди, тривало зберігається малохмарна, жарка, суха погода. Літні сезони 20132017 рр. відзначаються високими максимальними температурами $+32,0-+36,0{ }^{\circ} \mathrm{C}$, загалом за літній сезон спостерігаємо велику кількість днів 3 максимальною температурою повітря вище $25^{\circ} \mathrm{C}$, у 2017 р. таких днів було більше сорока. Найбільша кількість опадів (у середньому 276 мм або 37 \% від річної кількості) випадає влітку. У 2014 р. ця сума становила 320,5 мм. У літні місяці $80 \%$ дощів випадає у вигляді злив та грозових дощів. Це особливо помітно в останнє десятиріччя. Закінчується літній сезон переходом середньодобової температури повітря через $+10{ }^{\circ} \mathrm{C}$, у бік зниження у третій декаді вересня, і починається осінь. Значну циклічність мають західні та південні циклони, які зумовлюють хмарну погоду з опадами. Внаслідок вторгнення холодних арктичних мас повітря, а також втрати тепла шляхом випромінення, восени відбувається охолодження повітря і грунту до заморозків. У середньому заморозки починаються в середині жовтня. Особливо небезпечні ранні осінні заморозки.

Осінь найкоротша з усіх сезонів, у середньому становить 76 днів. Кількість опадів в осінні місяці зменшується, відповідно до загального зниження температури та вологості повітря, і становить в середньому 140,5 мм опадів (19\% від річної кількості). Найдовшу осінь спостерігали у 2015 р. - 96 днів, а найкоротшу 64 дні - у 2014 р., 2016 р. Тривалість періоду з температурою повітря від $+10{ }^{\circ} \mathrm{C}$ до $+5{ }^{\circ} \mathrm{C}$ становить близько місяця. Наприкінці жовтня відбувається перехід добової температури повітря через $+5{ }^{\circ} \mathrm{C}$ в бік зниження. Відтоді припиняється вегетація.

Температура повітря за останні десять років динамічно змінювалася, середні значення добової, максимальної і мінімальної температур, їхні екстремальні значення не перевищували гранично допустимі для цього регіону (рис. 1) (Prots-Kravchuk, 1972).

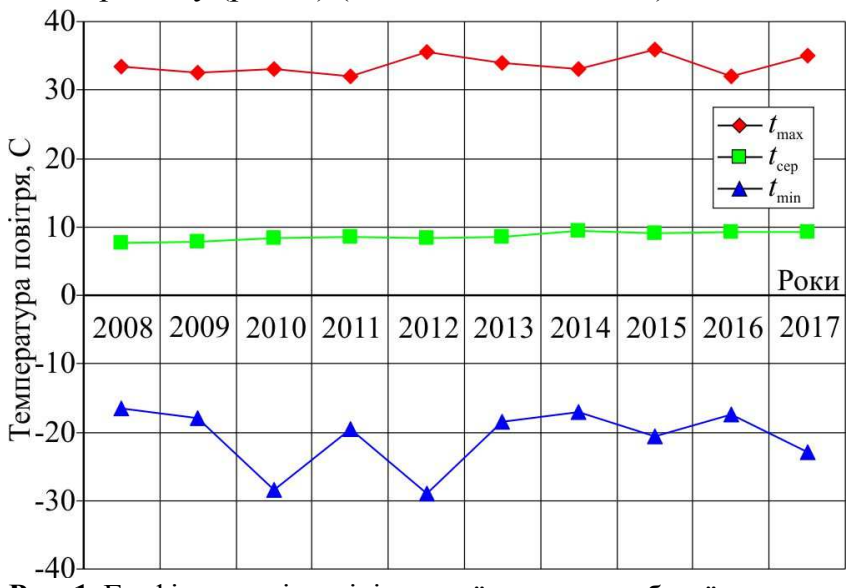

Рис. 1. Графік динаміки мінімальної, середньодобової, максимальної температури за 2008-2017 pp.

Мінімальна температура, за даними спостережень 3 2008 по 2017 pp. становила $-29,5^{\circ} \mathrm{C}$, а максимальна $+36,0^{\circ} \mathrm{C}$, що не перевищує граничні значення за попередні роки, які становили $-34,0{ }^{\circ} \mathrm{C}$ i $+36,0{ }^{\circ} \mathrm{C}$ відповідно. Середньорічна температура повітря змінювалась від $+8,0^{\circ} \mathrm{C}$ до $+9,6^{\circ} \mathrm{C}$, середнє багаторічне значення за досліджуваний період становить $+8,9^{\circ} \mathrm{C}$, за попередні періоди - $+7,0-7,8^{\circ} \mathrm{C}$ (Kosyk \& Skobalo, 2006), або +7,5 ${ }^{\circ} \mathrm{C}$ (табл. 2) (Prots-Kravchuk, 1972).

Табл. 2. Середньорічні показники температури повітря в заповіднику (дані метеостанції)

\begin{tabular}{|c|c|c|c|c|}
\hline \multirow{2}{*}{ Рік } & \multicolumn{3}{|c|}{$\begin{array}{c}\text { Середній багаторічний показник добової } \\
\text { температури повітря, }{ }^{\circ} \mathrm{C} / \text { відхилення }\end{array}$} & \multirow{2}{*}{$\begin{array}{l}\text { Опади за } \\
\text { рік, мм }\end{array}$} \\
\hline & за рік & $\begin{array}{c}\text { за січень - } \\
4,1\end{array}$ & $\begin{array}{c}\text { за липень } \\
+17,8\end{array}$ & \\
\hline 2008 & $9,1 /+1,6$ & $-1,0 /+3,1$ & $18,2 /+0,4$ & 613,4 \\
\hline 2009 & $8,8 /+1,3$ & $-2,7 /+1,4$ & $20,4 /+2,6$ & 854,0 \\
\hline 2010 & $8,3 /+0,8$ & $-7,1 /-3,0$ & $20,8 /+3,0$ & 969,0 \\
\hline 2011 & $8,6 /+1,1$ & $-1,6 /+2,5$ & $19,3 /+1,5$ & 638,2 \\
\hline 2012 & $8,0 /+0,5$ & $-2,6 /+1,5$ & $21,5 /+3,7$ & 783,1 \\
\hline 2013 & $8,5 /+1,0$ & $-3,8 /+0,3$ & $18,8 /+1,0$ & 728,7 \\
\hline 2014 & $9,5 /+2,0$ & $-2,2 /+1,9$ & $20,3 /+2,5$ & 720,6 \\
\hline 2015 & $9,6 /+2,1$ & $0,2 /+3,9$ & $19,8 /+2,0$ & 738,7 \\
\hline 2016 & $9,3 /+1,8$ & $-3,4 /+0,7$ & $19,6 /+1,8$ & 866,3 \\
\hline 2017 & $9,2 /+1,7$ & $-5,7 /-1,6$ & $19,1 /+1,3$ & 778,5 \\
\hline Середнє & $8,9 /+1,4$ & $-3,3 /+0,8$ & $19,8 /+2,0$ & 760,5 \\
\hline
\end{tabular}

Результати табл. 2 свідчать про локальні зміни клімату, які виражаються у збільшенні температури повітря у середньому на $1,4{ }^{\circ} \mathrm{C}$ за останні десять років і на $1,7^{\circ} \mathrm{C}$ - за останні п'ять років. Тобто межу $1,5^{\circ} \mathrm{C}$, яку рекомендує Міжурядова група експертів зі змін клімату, як крайню, територія заповідника вже перейшла, тому очевидно, необхідно розробити заходи, які б сповільнили цей процес. Середня температура січня зросла на $0,8^{\circ} \mathrm{C}$, а липня - на $2,0^{\circ} \mathrm{C}$ за десятиріччя.

Опади мають виражений літній максимум. Ceредньорічна сума опадів становить у середньому 760 мм. В окремі роки спостерігаємо значні коливання 
як у розподілі опадів за місяцями, так і в загальній кількості за рік (рис. 2).

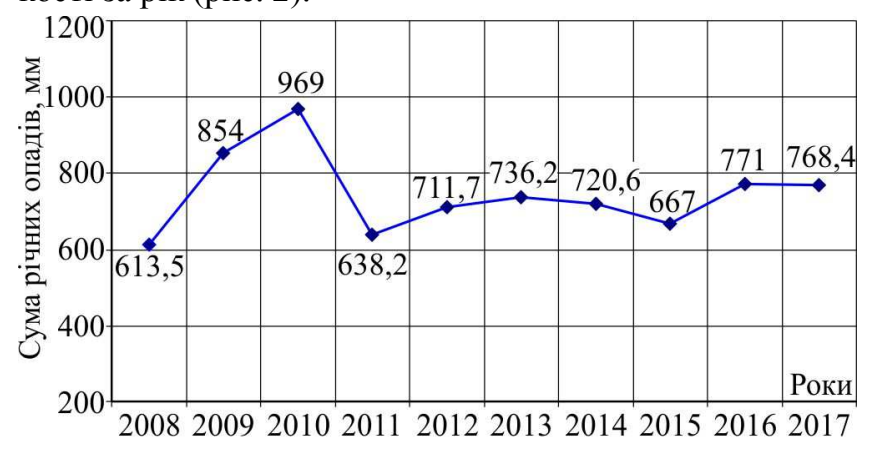

Рис. 2. Динаміка суми річних опадів у заповіднику

Як видно на рис. 2, найбільша річна сума опадів досягає 969 мм у 2010 р., i, навпаки, в 2008 р. вона була дуже малою і становила 613,4 мм, проте локальні прояви змін клімату виражаються у характері та інтенсивності опадів. Зливи, які проходять останнім часом, сильно ускладнюють роботу аграріїв, пошкоджують сільськогосподарські культури. За кілька годин випадає півмісячна або майже місячна норма опадів: 16.06.2015 р. була злива - 30 мм; 29.06.2015 р. - 45 мм; 4.05.2017 р. пройшла сильна злива 3 градом, опадів за день випало 31,5 мм; 30.05.2017 p. - 56,7 мм випало за дві години. Такі зливи часто ускладнюються сильними поривами вітру - понад $20 \mathrm{~m} / \mathrm{c}$, локальними смерчами, ураганами або градом (20.05.2013 р.). Зафіксовано зміни відносної вологості повітря: середньорічна вологість дорівнює 74 \%, низьку вологість спостерігаємо весною: у квітні 2015 р., у травні 2013 р. в окремі дні опускалася нижче $50 \%$, що $є$ аномальним.

Висновки. На території природного заповідника "Розточчя" зафіксовано локальні прояви зміни клімату, які виражаються у такому:

- середньорічна температура повітря за останні десять років зросла на $1,4{ }^{\circ} \mathrm{C}$, а за останні п'ять років - на $1,7^{\circ} \mathrm{C}$;

- тривалість весни зменшується, характерними рисами сезону є низька вологість повітря, холодні ночі, теплі дні, незначна кількість опадів, що утруднює роботу аграріїв;

- тривалість літа збільшується і становить 110-120 днів, сума ефективних температур зростає;

- в останнє десятиліття знизився рівень грунтових вод, змінився характер опадів - дощ випадає у вигляді сильних короткочасних злив, за одну зливу може випасти місячна норма опадів;
- збільшилася кількість днів у році з низькою відносною вологістю повітря;

- почастішали аномальні явища природи: сніголами, вітровали, буревії, трапляються смерчі, урагани, які завдають збитків населенню - руйнують будівлі, знищують урожаї $\mathrm{c} / \Gamma$ культур.

\section{Перелік використаних джерел}

Andriienko, T. L. (2002). Prohrama Litopysu pryrody dlia zapovidnykiv ta natsionalnykh pryrod-nykh parkiv: metod. posibn. Kyiv: Vyd-vo "Akademperiodyka", 103 p. [In Ukrainian].

Babichenko, V. M., \& Zuzuka, F. V. (1998). Klimat Lvova. Lutsk, 346 p. [In Ukrainian].

Entsyklopediia. (1990). Heohrafichna entsyklopediia Ukrainy. (Vol. 3). Kyiv: URE, 480 p. [In Ukrainian].

IPCC. (2018). Summary for Policymakers of IPCC Special Report on Global Warming of $1.5^{\circ} \mathrm{C}$ approved by governments, $36 \mathrm{p}$. Retrieved from: https://www.ipcc.ch/pdf/session48/pr_181008_P48_spm en.pdf.

Kosyk, L. B., \& Skobalo, O. S. (2006). Klimatychna ta fenolohichna kharakterystyka pryrodnoho zapovidnyka "Roztochchia". Mizhvidomchyi naukovo-tekhnichnyi zbirnyk Natsionalnoho lisotekhnichnoho universytetu Ukrainy. Lisove hospodarstvo, lisova, paperova i derevoobrobna promyslovist, 32, 82-86 p. [In Ukrainian].

Kryvoruchenko, Z. R. (2014). Tendentsii ta mozhlyvi naslidky hlobalnykh ta rehionalnykh zmin klimatu. Dnipropetrovskyi derzhavnyi ahrarno-ekonomichnyi universytet. Elektronne naukove fakhove vydannia "Derzhavne upravlinnia: udoskonalennia ta rozvytok", 9. Retrieved from: http://www.dy.nayka.com.ua. [In Ukrainian].

Litopys pryrody (2008-2017). Pryrodnyi zapovidnyk "Roztochchia", cmt. Ivano-Frankove. Kn. (pp. 22-31). [In Ukrainian].

Molozhnikov, V. N. (1976). Fenologiya prirodnyih yavleniy SeveroVostochnogo Pribaykalya. V k.: Prirodnyie usloviya Severo-Vostochnogo Pribaykalya. Novosibirsk. [In Russian].

Prots-Kravchuk, H. L. (1972). Klimat. Pryroda Lvivskoi oblasti. Lviv: Vyd-vo Lvivskoho un-tu, (pp. 40-58). [In Ukrainian].

Shults, H. (1981). Obshchaia fenolohyia. Leningrad: Nauka, 188 p. [In Russian].

Skobalo, O., Horban, I., \& Hrebelna, V. (2013). Fenoklimatychna periodyzatsiia $v$ zapovidnyku "Roztochchia". Visnyk Lvivskoho universytetu. Lviskyi natsionalnyi universytet im. I. Franka. Ser. Biolohichna, 63, 98-109 p. [In Ukrainian].

Stocker, T. F., Qin, D., Plattner, G.-K., Tignor, M., Allen, S. K., Boschung, J., Nauels, A., Xia, Y., Bex, V., \& Midgley, P. M. (Eds.). (2013). IPCC, Climate Change 2013: The Physical Science Basis. Contribution of Working Group I to the Fifth Assessment Report of the Intergovernmental Panel on Climate Change. Cambridge University Press, Cambridge, United Kingdom and New York, NY, USA, 1535 p.

Г. В. Стрямец1, В. Е. Гребельная 1, О. С. Скобало1, С. П. Стрямец1,2

${ }^{I}$ Природный заповедник "Расточье", пгт Ивано-Франково, Украина

${ }^{2}$ Национальный университет "Львовская политехника", г. Львов, Украина

\section{ЛОКАЛЬНЫЕ ПРОЯВЛЕНИЯ ИЗМЕНЕНИЙ КЛИМАТА НА ПРИМЕРЕ ПРИРОДНОГО} ЗАПОВЕДНИКА "РАСТОЧЬЕ"

Приведен анализ метеопоказателей, зафиксированных метеостанцией заповедника за последние десять лет (20082017 гг.). Установленная продолжительность сезонов отмечается сильной вариабельностью, это является признаком климатических изменений: самая короткая за исследуемый период зима длилась 30 дней, а самая длинная - 125 дней. Продолжительность весны уменьшается, характерными чертами сезона является низкая влажность воздуха, холодные ночи, теплые дни, незначительное количество осадков, что затрудняет работу аграриев. Увеличивается продолжительность лета, среднее значение достигает 112 дней. Отмечено, что изменился характер осадков - дождь выпадает в виде сильных кратковременных ливней, за один ливень иногда выпадает месячная норма осадков; увеличилось количество дней в году с высокой температурой воздуха, увеличилась продолжительность вегетационного периода в среднем на 9 дней. На территории природного заповедника "Расточье" зафиксированы другие локальные проявления изменения климата, которые выражаются в следующем: среднегодовая температура воздуха за последние десять лет выросла на $1,4{ }^{\circ} \mathrm{C}$, а за последние пять лет - на $1,7{ }^{\circ} \mathrm{C}$, что превышает норму $1,5^{\circ} \mathrm{C}$, рекомендованную экспертами МГЭИК; участились аномальные явления природы: снеголомы, 
ветровалы, случаются смерчи, ураганы, которые наносят ущерб населению- разрушают здания, уничтожают урожай сельскохозяйственных культур.

Ключевые слова: продолжительность сезонов; среднесуточная температура воздуха; осадки; аномальные явления.

G. V. Stryamets', V. O. Hrebelna1, O. S. Skobalo1, S. P. Striamets ${ }^{1,2}$

${ }^{1}$ Roztochia Nature Reserve, Ivano-Frankove, Ukraine

${ }^{2}$ Lviv Polytechnic National University, Lviv, Ukraine

\section{LOCAL EFFECTS OF CLIMATE CHANGE ON THE EXAMPLE OF THE ROZTOCHYA NATURE RESERVE}

Global climate change has been documented as increasing the average soil temperature and atmosphere, the temperatures of the ocean, as well as the increase of the level of the world oceans. Local climate studies are crucial for understanding the broader picture of climate change; therefore their analysis is quite necessary. Meteorological observations in Roztochya Nature Reserve are performed according to generally accepted methods. Air temperature changes are recorded every three hours, precipitation amount are recorded every day. Statistical processing of data was carried out. Phenological observations were conducted in accordance with Schulz's methodology (1981), division into seasonal and subseasonal recommendations of the Program of the Chronicle of Nature (Andriienko, 2002). The work analyzes the meteorological data recorded by the meteorological station of Roztochya Nature Reserve for the last ten years (2008-2017). The established duration of the seasons is marked by strong variability, which is a sign of climate change: the shortest period of the study period, winter, lasted for 30 days, and the longest period was 125 days. The duration of the spring is decreasing; the characteristic features of the season are low humidity, cold nights, warm days, low rainfall, which causes difficulties for agrarians to work. The length of the summer increases, the average reaches 112 days. It is noted that the nature of precipitation has changed - the rain falls in the form of strong short-term showers, a monthly rainfall rate may fall for one time; the number of days in a year with a high air temperature increased, as well as the duration of the growing season on an average of 9 days. On the territory of Roztochya Nature Reserve, other local signs of climate change have been recorded, which are expressed in the following: the average annual air temperature over the past ten years has increased by $1.4{ }^{\circ} \mathrm{C}$, and over the last five years by $1.7{ }^{\circ} \mathrm{C}$, which exceeds the norm of $1.5^{\circ} \mathrm{C}$, prognosed by experts of IPCC; anomalous phenomena of nature became more frequent: snowflakes, winds, storms, tornadoes, and hurricanes that cause damage to the local population destroy buildings and agricultural crops.

Keywords: duration of seasons; average daily air temperature; precipitation; abnormal phenomena. 